UDC 347.91/.95(497.5)

DOI: $10.5937 / R K S P P 2101121 U$

ALAN UZELAC

\title{
ACCOUNTABILITY AND TRANSPARENCY IN CIVIL JUSTICE SOME GENERAL REMARKS AND A VIEW FROM CROATIA
}

The paper analyses the notions of judicial accountability and transparency from a Croatian perspective. The prolonged transition period and the EU accession process underlined the importance of an independent but effective judicial system. The need to secure mechanisms that would enhance societal and legal accountability of judges and other judicial professionals is strongly affected by the developments in 1990's and early 2000s when new judicial elites, still influenced by past practices but protected by an overemphasized and misunderstood notion of judicial independence, created a closed professional group, a 'state within a state. Massive inefficiency and weak systems of liability call for a new approach. While describing some typical issues encountered in Croatia, this contribution strives to lay down some elements for rethinking of judicial accountability and transparency in civil justice systems of Central and South-Eastern Europe.

Key words: civil justice, judicial accountability and transparency, Croatia, independence of judiciary

\section{CONCEPT AND DEFINITION OF JUDICIAL ACCOUNTABILITY AND TRANSPARENCY}

The notion of 'accountability' in respect of judicial power, and in particular in respect of judges as holders of judicial offices, is a notion which is currently

Prof. Dr. Alan Uzelac, Full Professor and Head of Department for Civil Procedure, Faculty of Law, University of Zagreb, e-mail: auzelac@pravo.hr; former member of the State Judicial Council (2011-2015). This paper is based on the author's report delivered for the World Congress of the International Association for Procedural Law held in November 2019 in Kobe (Japan). 
gaining on importance. This is, however, still a notion which is belonging more to political science and critical examination of legal institutions than a notion which is clearly and uniformly defined by law. ${ }^{1}$ The same goes for the notion of 'transparency.' However, there is an emerging body of writings on these topics produced in the past decade. ${ }^{3}$

In Croatia, both concepts were becoming popular in public due to two parallel developments. The one development was local and national development. Namely, when Croatia gained independence in the beginning of 1990's and started the transition process from the party-driven socialist state which adhered to the concept of unity of power to the pluralist market economy which recognizes separation of powers, the main direction of judicial reforms was directed towards strengthening the independence of judicial power. Croatian Constitution of 1991 therefore emphasizes the independence of judicial power (Art. 115/2), permanent nature of judicial office (Art. 120/1), personal authority of individual judges as judicial office-holders (Art. 118/1), judicial immunity from prosecution (Art. 119/1) which implies also immunity from any liability for the opinions expressed by judges (Art. 119/2) and the prohibition from imprisonment of judges without the previous approval of the State Judicial Council (Art. 119/3). The Constitution also provided a closed list of reasons for removal of judges, which basically permits the removal of judges only if they have been finally convicted of crimes which make them unfit to hold the office or if they have been found disciplinary liable for the reason of grave disciplinary offences by the State Judicial Council (comp. Art. 120/2). The Constitution also defined the State Judicial Council as the body which secures judicial independence (Art. 121/1) by deciding on appointment, promotion, transfer and removal of judges, as well as on their disciplinary liability (Art. 121/2). This is reinforced by the composition of the State Judicial Council whose majority consists of judges elected by their peers, with only

1 The notions of 'accountability' and 'transparency' are more often mentioned in the context of public administration, see e.g. the Compendium of basic terminology in governance and public administration adopted by the UN Economic and Social Council in 2006, E/C.16/2006/4.

2 Compare Wim Voermans, "Judicial transparency furthering public accountability for new judiciaries”, Utrecht Law Review, No. 1, Vol. 3, 2007, 148-159.

3 See Independence, accountability, and the judiciary (eds. Guy Canivet, Mads Andenas, Duncan Fairgrieve), British Institute of International and Comparative Law, London, 2006; John Bell, Judiciaries within Europe: a comparative review, Cambridge University Press, Cambridge, 2010; Democratization and the judiciary: the accountability function of courts in new democracies (eds. Siri Gloppen, Roberto Gargarella, Elin Skaar), Cass, London, 2004; Open justice: the role of courts in a democratic society (eds. Burkhard Hess, Ana Koprivica Harvey), Nomos, Baden-Baden, 2019; Daniela Piana, Judicial accountabilities in new Europe: from rule of law to quality of justice, Ashgate, Farnham, 2010. 
a marginal participation of university professors and members elected by the Parliament.

On the other hand, neither the Constitution nor the other sources of law mention the 'accountability' and 'transparency' as separate notions, outside of the mention of disciplinary liability (also limiting this liability, see supra) and the provision that the court hearings and court judgments have to be public.

While the law emphasized judicial independence, the developments in the 1990's did not substantively contribute to this independence. On the contrary, due to war situation and an authoritarian government, this independence was substantially reduced. ${ }^{4}$ This led to a number of de facto political appointments and dismissals, which did not improve the quality of judicial power. Starting with the 2000's, the political pressure and political influence on judiciary decreased, and the constitutional guarantees began to be taken more seriously.

However, such rediscovery of judicial independence caused a paradoxical phenomenon: instead of development of independent judiciary of high quality, the institutional independence and self-management of judicial power led to freezing of a situation in which judicial office holders who were appointed in the 1990's continued to discharge judicial functions, though their quality and the motives for their appointment were often below the desired standards.

The result of these developments has been that the operation of judicial power experienced (and continued to experience) serious difficulties. A number of decisions of low quality raised attention in public media, while at the same time the national judiciary suffered a crisis of efficiency, with a large volume of backlogged cases and the significant delays in a large number of judicial proceedings. ${ }^{5}$ In this context, the trust in the judiciary became very low. In the beginning of 2000's, courts were the least trusted social institutions, enjoying less trust than police, church, presidency, parliament, trade unions, NGO's and private enterprise. This led to ever louder demand in the public for more accountability and more transparency in respect to courts and judges.

The second development was the international one. As Croatia was preparing for the membership in the European union, it had to comply with a series of criteria in the context of the European accession process. Among these criteria, those that were the hardest to comply with were contained in the Chapter 23 of the EU accession negotiations, which related to judiciary and human rights. This

4 See more in Alan Uzelac, "Role and Status of Judges in Croatia", Richterbild und Rechtsreform in Mitteleuropa (ed. Paul Oberhammer), Wien, 2000, 23-66.

5 More on that topic in Alan Uzelac, "Delays and Backlogs in Civil Procedure. A (South) East European Perspective", Revista de Processo, Vol. 39, 2014, 39-64. 
chapter was the last one to be completed in 2011 prior to Croatian accession to EU membership in 2013. The EU negotiators noted the problematic state of Croatian judiciary and requested a significant improvement as a condition for the closure of the negotiations. ${ }^{6}$

As a part of the measures that were agreed in order to complete the process of accession, some had direct reference to accountability and transparency. For instance, the EU Commission requested a decisive improvement of efficiency, cutting down the number of backlogged cases, reducing the duration of the judicial proceedings and the introduction of a merit-based system of appointment and promotion of judges. Education of judges and extension of powers of the institution for education of judges, the Judicial Academy, was also a part of the deal. ${ }^{7}$ Croatia finally complied with most of the requirements, though in the years that followed the Croatian accession many of the agreed measures were dismantled or substantively reversed.

In any case, the notion of judicial accountability and transparency gained on importance in the past period, mainly in the context of public dissatisfaction with the functioning of the judicial sector. Former president of the Croatian state, Dr. Ivo Josipović, summarized what is an overwhelming feeling in the public: judges have become "a state within a state", they act as a privileged sect and often put professional solidarity before the public good. ${ }^{8}$ All in all, there is a need for mechanisms that would increase their accountability and generally raise the level of transparency in the operations of civil justice.

But, while there seems to be a consensus of civil society in this respect, it is hard to say that there is a dominant theoretical view or doctrine on judicial accountability. Most legal writers and law professors regard this to be a sensitive subject, tend to avoid expression of their views on the topic and hide behind the positivist approach to law. Therefore, the concept of judicial accountability still has fuzzy contours. What is certain is that those who use it have a critical view on the current situation in the national judiciary, and that this notion is used as an antithesis to (overly broad) notion of judicial independence. In this sense, the need to increase judicial accountability was named as justification of a series of mea-

6 See Alan Uzelac, "The Rule of Law and the Judicial System: Court delays as a barrier to accession”, Croatian Accession to the European Union (ed. Katarina Ott), IJF, Zagreb, 2004, 105-130.

7 The agreed changes were regularly reflected in the periodical review in Progress Reports issued annually by the European Commission, see $h t t p: / / w w w . m v e p . h r / e n / c r o a t i a-a n d-t h e-e u r o p e-$ an-union/negotiation-process/reports/european-commission/, last visited on 29 April 2021.

8 Statement delivered by Ivo Josipović at think-tank annual meeting, Tripalovi dani u Sinju, 7 June 2019. 
sures which were undertaken with variable success in the past decade (see more infra).

The same can be stated about the notion of 'transparency', which is sometimes overlapping with the notion of 'accountability'. In order to increase the accountability, the justice needs to be dispensed in public, and be open to public scrutiny. Also, public suspicion about corruption in the judiciary can be best met if all relevant data on the assets of judicial office holders is 'transparent', i.e. reported and - with or without limitations - open to the public for inspection so that (in theory) any illicit enrichment is easily spotted. Still, 'accountability' and 'transparency' have different focus and scope. 'Transparency' is inherent to good administration of justice, which must be visible and easily comprehensible for the citizens. It has a value in itself, in particular in the context of creating public trust in judiciary; but, transparency also has an instrumental aspect. 'Transparency' is a precondition for 'accountability', since it serves as an instrument that helps achieving accountable justice.

\section{METHODS OF SECURING JUDICIAL ACCOUNTABILITY AND TRANSPARENCY}

Since notions of 'transparency' and 'accountability' are basically meta-legal concepts which are open to individual interpretations, they are often interpreted in different ways. To avoid misunderstanding, I will present Croatian ways of securing judicial accountability and transparency on the basis of my own systematization of the legal devices that serve for that purpose.

The notion of 'judicial accountability' deals with both individual and collective responsibility of courts and judges. They must discharge their functions in an honest and competent way, without improper influences, free from corruption and in line with the applicable provisions of law. Law needs to be interpreted scrupulously, consciously and according to intimate conviction and best judgments of every member of the tribunal to which the case has been entrusted. This notion also denotes the desire to ensure that judges are loyal to their social goals and functions, that they need to put public good and the interests of the parties before their own private interests and agendas. 'Transparency' in this context means that all these elements need to be verifiable by the public, and that every information on operation of justice system needs to be accessible, except in situations where transparency would clearly have a disproportionately negative effect on other values and legally protected rights and interests.

In Croatian law, legal methods developed over the past two decades in order to secure the accountability and transparency can be functionally divided in 
eight groups. The first four devices deal mainly with accountability, and the last four mainly with transparency. They are as follows:

1. Legal devices that sanction improper and illicit behavior of judicial office holders, such as rules on disciplinary liability and disciplinary procedure.

2. Legal devices that have the aim to ensure orderly operation of courts, such as rules on judicial administration and case management.

3. Legal devices that aim at even distribution of tasks and define framework of quantitative criteria for discharging of judicial functions.

4. Legal devices that secure quality control of judicial decisions and uniform application of law, such as the rules on legal means of recourse and interpretative statements of higher courts.

5. Legal devices that secure publicity of individual judicial proceedings, including publicity of trials and the right of public insight into court files, and the right to public comments on pending judicial proceedings.

6. Legal devices which serve as prevention against illicit enrichment, such as rules on asset declaration for current judicial office holders.

7. Legal devices that ensure transparency of judicial decisions, such as systematic publication of laws, statutes and court judgments and other decisions.

8. Legal devices that provide transparency as to overall functioning of the judicial system, including regular and detailed information on the quality and efficiency of the judicial system.

All of these methods and legal devices have been regulated by laws or respective routines and practices. However, the multitude of rules does not mean that the rules are enforced in an optimal way. As described supra, the public opinion on judiciary and its quality is low, and this is reinforced by practically any comparative study on the operation of national justice systems.

For example, the EU Justice Scoreboard consistently finds that Croatian citizens and companies have the lowest trust in the independence of judges among all EU Member States. ${ }^{9}$ At the same time, the World Economic Forum ranked Croatia at place 140 of 141 countries according to the criterion of the efficiency of the legal framework in settling disputes. ${ }^{10}$

9 See EU Justice Scoreboards for 2019 and 2020, https://ec.europa.eu/info/publications/2019eu-justice-scoreboard-factsheets_en, https://ec.europa.eu/info/files/summary-2020-eu-justice-scoreboardfactsheet_en, p. 8, Figures 9 and 11.

10 World Economic Forum, The Global Competitiveness Report 2019, 175 (Public-sector performance), http://www3.weforum.org/docs/WEF_TheGlobalCompetitivenessReport2019.pdf, last visited on 29 April 2021. 
Consequently, there are a lot of issues which still need to be addressed in a proper way; I will give more details in the following brief survey of the eight groups of legal devices.

\section{Rules and practices on the discipline of judges}

The Constitutional provisions on the disciplinary liability of judges are further elaborated in the Law on State Judicial Council (LSJC). ${ }^{11}$ The State Judicial Council is a body which consists of the majority of judges (seven out of eleven members), elected by vote of their fellow judges according to the scheme which ensures participation of all levels of courts: two elected Supreme Court members, two elected judges of appellate courts, two elected judges of first-instance courts of general jurisdiction, and one judge from the ranks of specialized courts (commercial, administrative or misdemeanor courts).

The law defines disciplinary offences of judges. ${ }^{12}$ The list of disciplinary offences was initially shorter, but in light of experiences it expanded to nine categories. Most of them are related to judicial accountability. They are:

1. Failure of a judge to orderly discharge judicial functions. This is in particular the case:

a.) if a judge fails to produce and dispatch judicial decisions without a good cause,

b.) if a judicial council (body of judicial self-government) gave a negative assessment of judge's discharging of his function,

c.) if a judge failed to produce on the annual basis less than $80 \%$ of decisions as defined by the framework criteria for quantitative assessment of judicial work (see more infra on the framework criteria),

d.) if a judge fails to treat cases in the prescribed sequence, or if he does not pay attention to their urgency.

2. Failure to timely react in cases found to be a violation of the right to a trial within a reasonable time (in separate proceedings where parties complained about the length of proceedings).

3. Undertaking activities or discharging functions incompatible with the judicial duty.

11 Law on the State Judicial Council, Official Gazette 116/10, 57/11, 130/11, 13/13, 28/13, $82 / 15,67 / 18,126 / 19$.

12 See Art. 62/2 LSJC. 
4. Inciting disturbances in the operation of the court which may affect the orderly operation of courts.

5 . Violation of official duty to keep confidentiality.

6. Offences against the dignity and reputation of court and judicial duty.

7. Failure to submit asset declaration forms within the set deadlines (see more infra on judicial asset declaration).

8. Failure to submit to assessment of physical and mental abilities needed to discharge judicial duty.

9. Violations of the provisions on the protection of personal data.

This lengthy list indicates a number of situations identified in the practice as problematic. Still, in spite of the long list of offences, in practice there are relatively few disciplinary sanctions against judges. They are also not reported regularly, and it seems that their frequency change with the composition of the State Judicial Council (new Council is elected every four years) and with the political situation (there were many more sanctions in the period prior to the accession to the EU than later).

Obviously, some councils were in the past more, and some less proactive in disciplinary proceedings. For instance, in 2016 and 2017 there were altogether 26 disciplinary proceedings. In the same period, only nine disciplinary decisions were made. Five cases were discontinued, in three cases judges were sentenced to monetary sanctions (withdrawal of a part of their salary), and only in one case a judge was dismissed from judicial office. In comparison, in 2011 and 2012 there were 76 proceedings and 43 decisions, out of which 3 dismissals, 7 monetary sanctions, 1 conditional dismissal, 23 admonitions, 6 discontinued cases, and 3 cases where no liability was found. ${ }^{13}$

This indicates that disciplinary proceedings may need to be redefined and reshaped in the future. The problematic issues that can be spotted are multiple. First, it seems that there was a relative leniency of (some) State Judicial Councils, where it seemed that the members were reluctant to sanction their peers. Second, there is a lack of capacity to conduct disciplinary proceedings effectively; eleven members of the Council work only part time in the Council, along their other duties, and there are no standing professional tribunals for disciplinary cases. Therefore, in various cases where indicted judges would use dilatory tactics and procedural maneuvers, it led to lengthy proceedings or even to discontinuance of the proceedings. Even very clear cases sometimes last unreasonably long time.

13 According to data provided by the Secretariat of the State Judicial Council. 
For instance, a rare case of a judge that was dismissed from office happened in 2019. ${ }^{14}$ But, this was a judge who was a problem from his first disciplinary proceedings in 2003. In 2011 he was caught by the police when receiving bribe. The criminal proceedings against him lasted six years. He was sentenced to four and half years of imprisonment for five criminal acts. Anyway, he was suspended from his office in 2011-2019 period and only removed from duty in 2019. In the meantime, he regularly received half of his salary, which is still more than the average salary in Croatia. ${ }^{15}$ In another case, a judge was suspended due to pending criminal proceedings for a period of eight years prior to his retirement, receiving half of his salary while not being active at all. ${ }^{16}$ Indeed, such cases raise public criticism regarding the lack of judicial accountability and inefficiency of the disciplinary proceedings against judges.

Finally, even in cases where judges were found accountable for disciplinary offences, they were entitled to a full-fledged appeal to the Constitutional Court. The Constitutional Court - also poorly equipped for conducting concrete disciplinary proceedings - sometimes issued decisions which sent mixed messages, striking down several of infrequent decisions that sanctioned judges for unorderly discharge of their functions.

\section{Judicial and court administration in the service of judicial accountability}

The proper measures of court administration and case management are another key to accountable judiciary. Even though general court administration does not have a direct connection to judicial accountability in individual cases, good court administration is a precondition for a transparent and accountable justice system. For instance, deficiencies in the system of service of process can delay or even block adjudication. This creates the impression of poor justice for the end users. The end users do not distinguish whether it is the poor administration or the poor adjudication that causes the problem, and then hold the judges accountable for the slow and ineffective justice.

14 Among other reports, see https://www.poslovni.hr/hrvatska/poznati-splitski-sudac-ide-uzatvor-a-mora-vratiti-i-novac-350662, last visited on 29 April 2021.

15 Compare https://www.jutarnji.hr/vijesti/hrvatska/zavrsio-u-remetincu-ali-i-dalje-prima-placu-sudac-pesutic-ce-dobivati-polovicu-primanja-sve-dok-ustavni-sud-ne-rijesi-njegovu-zalbu-8841935, last visited on 29 April 2021.

16 See https://www.vecernji.hr/vijesti/umirovljen-sudac-koji-od-2011-nije-radio-a-zaradio-milijun-kuna-1352785, last visited on 29 April 2021. 
But the argument also goes the other way: in a system with a number of administrative deficiencies, some judges (and perhaps even a majority of them) can find an excuse for their poor performance in the outside circumstances. They start to blame the other elements of judicial system even where they could themselves use more appropriate methods of case management and deal with the issues with the available means. Thus, a vicious circle occurs, the blame is always shifted to the others, and no one is ultimately held accountable.

In Croatia, court administration is an activity which is within the shared responsibility of the judicial power and the Ministry of Justice (insofar, the law distinguishes between the "court administration" and "judicial administration" though their functions are fundamentally the same). As in all situations of shared responsibility, the fuzzy division of labor is a cause of tensions and problems. The Ministry of Justice belongs to the executive branch of government and is responsible to the Government. It is responsible for good administration of justice; it is also competent to propose the budget for the courts and prosecution offices (but limited by the budgetary negotiations, and dependent on the approval from the Ministry of Finance).

On the other hand, the Ministry of Justice has no direct competence in the appointment, transfer and removal of judges. The exception is related to the right of the Minister of Justice to give initiative for the conduct of disciplinary proceedings against judges, but the decision is ultimately in the hands of the State Judicial Council. ${ }^{17}$ In practice, the Minister uses this power infrequently, also due to the fact that the State Judicial Council dislikes such initiatives and often rejects them. The Ministry of Justice can enforce its administrative decisions through the court presidents, who are the principal organs of court administration. Yet, the competences of the Ministry are limited, as the court presidents are appointed independently by the SJC, whereas the Ministry can only give their unbinding opinion about the candidates in the process of their appointment.

While all important decisions on appointment, promotion, removal and discipline of judges and court presidents are within the competence of the State Judicial Council, the SJC does not have any powers or liabilities for the judicial administration. It also does not dispose of any budgetary influence (even not as to its own budget, which is rather modest). Thus, it is not surprising that seeking accountability for court administration is a difficult process, and that reform measures often encounter complications in their enforcement.

17 Compare Art. 67/2 LSJC. 
As a measure to strengthen the position of the Ministry of Justice and improve the accountability for judicial administration, the 2013 Law on Courts ${ }^{18}$ provided for the establishment of a special unit, called the Judicial Inspection. ${ }^{19}$ The judicial inspectors are established with the view to control orderly exercise of judicial administration. They are supposed to be appointed from the ranks of judges assigned to the Ministry of Justice or among the officials of the Ministry of Justice who satisfy conditions for senior judicial officials.

In practice, the judicial inspection of the Ministry of Justice has not proved to be very effective. The law was amended several times since 2013 in the attempt to improve its operation. Still, until 2016 the quota of judicial inspectors (6 inspectors) was not fulfilled (only four inspectors were operating). In the public media, it was also noted that the judicial inspection was much more agile in the period of negotiations with the EU than later, after Croatian entry into the EU. So, for instance, while in 2013 the Judicial Inspection conducted 23 inspection processes and initiated nine disciplinary proceedings, in 2015 there were only two inspection processes, and no disciplinary proceedings were initiated. ${ }^{20}$ In 2019 , in another wave of changes to the judicial inspection, new rules on selection and appointment of judicial inspectors were adopted. ${ }^{21}$ As information on the operations of the Judicial Inspection are unsystematic and scarce, so far there is no indication of any substantive change in its modus operandi.

\section{Quantitative criteria for evaluation of judicial officials}

One of the notorious starting points of judicial reforms in Croatia was the observation that judges and courts in different areas of Croatia have a rather different caseload. Further on, it has been noted that even in the same courts different judges have rather different outputs. As a device for ensuring that judges have comparable workload, and that they deal with the comparable number of comparable cases, several measures were introduced.

First, in a lengthy process that lasted over a decade, the court network was revised and the number of courts was significantly reduced. Since 2008, the num-

18 Law on Courts (Zakon o sudovima, LC), Official Gazette 28/13, 33/15, 82/15, 82/16, 67/18, $126 / 19,130 / 20$.

19 Arts. 80-84 LC.

20 See e.g. https://slobodnadalmacija.hr/novosti/hrvatska/clanak/id/304482/pravosudna-inspekcijasudovi-su-nam-bez-mane, last visited 29 April 2021.

21 See Pravilnik o postupku izbora pravosudnih inspektora i načinu provedbe inspekcijskih nadzora, Official Gazette 106/2019. 
ber of municipal courts has been reduced from 108 to 67 , and the number of misdemeanor courts from 114 to 63.

Since 2015, the number of municipal courts has been further reduced from 67 to 24, and the number of misdemeanor court from 63 to 22. Finally, since 2019, misdemeanor courts have been merged with the municipal courts so that, at present, there are 34 municipal courts. In such a way, the differences of caseloads between smaller courts, where judges in the past sometimes had ten times less cases than the heavily burdened courts in the urban areas, were reduced or eliminated.

At the individual level, judicial accountability for diligent work is quantified in the document named "Framework Standards for the Workload of Judges" (Okvirna mjerila za rad sudaca). ${ }^{22}$ This is the document issued on the basis of the Law on Courts by the Minister of Justice, who enacted this document after having obtained the opinion of the General Assembly of the Supreme Court (so-called "Extended Assembly", as it consists not only of supreme court judges, but also of representatives of other courts in the country).

The Framework Standards were changed several times. In the beginning, there were only a few categories of cases. Over time, the number of categories has increased. Until the end of 2019, there were 21 categories of litigious cases. As an example, it was regarded that a judge should regularly decide 500 divorce cases in a year, or 150 work dismissal cases, or 120 mobbing cases, or 165 damage compensation cases. The latest Framework Standards, effective from November 2019, have again reduced the number of categories, with a more uniform set of criteria. In litigious sphere, the regular standard is 200 litigious cases, or 220 family disputes, 120 mobbing and anti-discrimination cases, or issuance of 500 payment orders. While a number of opinions were procured in the process of amending the Framework Standards, no objective data justifying the changes were provided, and no systematic research on time-use in courts has ever been conducted. Thus, there is still ample space for legitimate doubts about the suitability and appropriateness of the prescribed criteria.

The framework standards are relevant for the assessment of judicial work, as well as for disciplinary proceedings against judges. The regular assessment of judges takes place when they apply for appointment to another court (regularly: when they apply for promotion), and when they raise their candidature for the post of the court president.

22 See https://mpu.gov.hr/UserDocsImages/dokumenti/Pravo\%20na\%20pristup\%20informacijama/Zakoni\%20i\%20ostali\%20propisi/Okvirna\%20mjerila\%20za\%20rad\%20sudaca.pdf, last visited on 29 April 2021. 
The assessment is undertaken by the bodies called 'judicial councils', which are formed at the level of the appellate courts. They regularly have $15 \mathrm{mem}$ bers, nine elected from the judges of the appellate and six from the first-instance courts. Among the most important functions of the judicial councils are the assessments of the judges which are produced on the basis of the methodology of assessment elaborated by the State Judicial Council. ${ }^{23}$ The judicial councils give their assessments in a numerical form, awarding a particular number of points for the five elements defined by law, with the maximum of 150 points. ${ }^{24}$ First of these elements is the number of decisions assessed on the basis of the framework standards (max: 60 points). The other important element is the quality of decisions, which is again assessed based on the ratio of confirmed and repealed decisions (maximum is also 60 points). The observation of deadlines and the participation in academic courses and other related activities (work in legislative drafting groups, teaching at university, membership in the judicial council, length of their judicial experience etc.) can in total bring a maximum of 30 points. The judges which have more than 130 points are rated as "excellent".

This scheme creates an impression of objectivity - and this was also its aim, as it was adopted based on the suggestions of the observers from the EU Commission in the EU accession process. Still, in practice it turned to be controversial. Some judges complained that these numerical assessments did not reflect the real quality of judges, in particular because the statistical assessment of work looked best for judges who dealt with simpler, more routine tasks than for those who were entrusted with "hard cases" and complex matters.

Some of these criticisms may have been right, but the reaction to them was certainly not appropriate. Namely, instead of conducting a thorough examination and fine-tuning of the quantitative and qualitative criteria, the State Judicial Council in the past years started to disregard legal provision commanding that the candidates for judges and court presidents must be appointed based on the number of points that they score in the process of assessment by the judicial council ( $\max 150$ points) and at the interviews by the State Judicial Councils (max 20 points).

Instead, after calculating the total number of points (that includes SJC's own points given at the interview), the State Judicial Council started to vote for the candidates irrespective of their numerical assessment, thereby appointing can-

${ }^{23}$ State Judicial Council, Methodology of judicial assessment (Metodologija izrade ocjene sudaca), see $h t t p: / / w w w . d s v . p r a v o s u d j e . h r / i n d e x . p h p / d s v / p r o p i s i / m e t o d o l o g i j a \_i z r a d e \_o c j e n e \_s u d a c a, l a s t$ visited 29 April 2021.

24 See Art. 97 LC. 
didates which scored significantly lower than the others. ${ }^{25}$ While this passed in some cases the scrutiny by the Constitutional Court, ${ }^{26}$ which held that "mechanical criteria cannot be the only decisive element", in several recent cases it led to appointments which raised suspicions of nepotism and clientelism, thereby again making problematic the main intention - accountability of judges who have to be awarded for excellent discharge of their functions by promotion based on the objective indicators. Consequently, the Constitutional Court also refined its position, striking down appointments in some of the most striking instances of arbitrary appointments. ${ }^{27}$

The devices for quality control of judicial decisions in individual cases (appeals and other means of recourse)

The oldest and most conventional method of control in civil procedure, aimed at securing accountability of judges, is the system of legal means of recourse that can be used by parties (and sometimes third persons) to scrutinize legal and factual findings of judges in individual cases.

In the context of Croatia as a post-socialist state, the mechanisms of appellate control were traditionally very elaborate. The socialist states generally did not have confidence in their judges and insisted on the multiple possibilities to scrutinize their decisions, often upon initiative of the state bodies (like public prosecutors). Croatia, as a part of former Yugoslavia, was not much different. It is also a country which belongs to a specific legal tradition, marked by the approach to law typical in the socialist states. ${ }^{28}$

${ }^{25}$ Just as an illustration, out of eight candidates for the High Commercial Court, in July 2016 the SJC appointed those in fourth and fifth place (see http://www.dsv.pravosudje.hr/index. php/dsv/odluke_dsv_a/odluke_52_sjednice_drzavnog_sudbenog_vijeca_1); in May 2016, the SJC appointed to County Court in Zagreb the candidates that were ranked 13th and 18th on the list of 23 persons (http://www.dsv.pravosudje.hr/index.php/dsv/odluke_dsv_a/odluke_44_sjednice_drzavnog_sudbenog_vijeca). Links last visited on 29 April 2021.

${ }^{26}$ See decisions of the Constitutional Court U-III-4818/2015, of 28 January 2016; UIII-5884/2011 of 29 April 2015; U-III-4631/2015 of 1 June 2016.

27 See U-III-281/2018 of 22 May 2018 (CC decision relating to the case in which the candidates ranking $71 \mathrm{st}$ and $73 \mathrm{rd}$ on the list were appointed, in spite of the fact that their assessment was mediocre under all objective parameters of the assessment).

${ }^{28}$ See more in Alan Uzelac, "Survival of the Third Legal Tradition?", Common Law, Civil Law and the Future of Categories (eds. J. Walker, O. G. Chase), Lexis Nexis, Markham, 2010, 377-396. 
Thus, the Croatian Constitution, just like the constitution of former Yugoslavia in the socialist period, recognizes the right of appeal against all judicial decision as a constitutional right. The appeals regularly suspend effectiveness of judicial decisions, and even final and binding judicial decisions can be challenged in several ways. This "fetishism of appeals" forms a specific psychology: according to prevailing opinion, first-instance decisions are only a provisional remedy which has not much value.

As an illustration, the appellate decisions that quash the first-instance judgments used to be rather frequent. When appeals were accepted on the merits, in about three out of four cases it used to lead to remittal of the cases for a new trial. All in all, this has contributed to length and ineffectiveness of judicial proceedings. ${ }^{29}$ Such practice (in German: Instanzenmentalität) and the possibility to have a judicial decision quashed multiple times (in theory: for an unlimited number of times) was found by the European Court of Human Rights to be contrary to the principle of fair trial. In particular, the ECtHR found this feature to be a systemic deficiency of the Croatian procedural law, as it can create a 'vicious circle' of judgments and their remittals that can potentially violate the right of the access to a court guaranteed by Art. 6 of the European Convention. ${ }^{30}$

Therefore, while legal means of recourse obviously can help in assuring accountable administration of justice, in Croatian case it is proved that their abundance can also have adverse effects. Instead of securing accountability, the multiple appellate processes obscure and delay accountability, due to the excessive length of appellate proceedings (in some Croatian courts, appellate decisions need three to five years to be made), plus the still prevailing practice of remittals (instead of reversals) by the appellate courts.

It should also be noted that the quality of control in individual cases depends on the quality of those who are in charge of such control. As previously hinted, the practice of judicial promotion to higher courts in Croatia has not always led to appointments of the best legal minds. Insofar, the appellate decisions are also sometimes flawed, and therefore can lead to quashing of impeccable decisions, and also to approval of decisions which should have been scrutinized. In the past several years, some reforms attempted to change the situation by introducing the

29 More in Alan Uzelac, "Ustavno pravo na žalbu u građanskim stvarima: jamstvo ispravnog pravosuđenja ili relikt prošlosti?”, Djelotvorna pravna zaštita u pravičnom postupku. Izazovi pravosudnih transformacija na jugu Europe. Liber amicorum Mihajlo Dika (eds. Alan Uzelac, Jasnica Garašić, Aleksandra Maganić), Pravni fakultet Sveučilišta u Zagrebu, Zagreb, 2013, 219-243.

30 See Aida Grgić, “The length of civil proceedings in Croatia - Main causes of delay”, Public and Private Justice. Dispute Resolution in Modern Societies (eds. Alan Uzelac, Cornelis Hendrik Van Rhee), Intersentia, Antwerpen-Oxford, 2007, 159. 
limit on the number of successive remittals, also trying to reduce cases in which judgments are quashed and remitted for retrial. So far, the success of such reforms was rather moderate.

\section{Publicity of judicial decisions}

The modern doctrine of civil procedure teaches us that publicity of judicial proceedings is in democratic states a rather important element for securing accountability of the judicial proceedings. The publicity of court proceedings, according to the doctrine of appearances, which was often referred to after the 1990s, secures that justice is not only done, but that it is also seen to be done. Translated into modern language, the publicity of judicial process is the principal device for transparency of the justice system.

The public insight into the course of trials enables the public to exercise a certain level of control over the judicial office holders, as it theoretically gives access to all relevant elements of judicial decision-making. The public can follow the process of evidence-taking; it can also follow legal arguments of the parties and observe the course of the trial. Thus, the public can assess how the material needed for the adjudication was assembled and check the grounds of the judicial decisions as well as the way how the courts and tribunals arrived at their conclusions. The publicity also serves for verification that the process was free from bias, that judges acted independently and impartially, and that no undue influence was exercised during the trial. Insofar, the publicity secures the transparency of the proceedings and raises the public confidence in the justice system, as the public can get assured that courts operate justly and properly. At least, this was the theoretical underpinning which was behind the model of the public, oral and immediate civil procedure as developed at the end of the $19^{\text {th }}$ century.

In Croatia, publicity of court hearings is protected by Constitution. Court hearings are public, and the court judgments have to be pronounced publicly. ${ }^{31}$ The publicity may be constrained only for necessary reasons, to protect the interests of morals, public order and national security. Publicity is excluded from judicial proceedings in particular when minors or family matters are concerned, or for the protection of privacy and keeping of secrecy of sensitive military, official or business data - but 'only to the extent strictly necessary in special circumstances where publicity would prejudice the interests of justice.' The same language,

31 Croatian Constitution (Official Gazette 56/90, 135/97, 08/98, 113/00, 124/00, 28/01, 41/01, 55/01, 76/10, 85/10, 05/14) Art. 117/1. 
copied from Art. 6 of the European Human Rights Convention, appears also in the Code of Civil Procedure in the provisions on exclusion of publicity. ${ }^{32}$

As much as the publicity remains important as an element of public control over judicial proceedings, in contemporary civil procedure in Croatia, due to a number of factors, it lost a lot of its practical significance. An overwhelming majority of judicial hearings, though technically public, has no external spectators. The reason is not only the technical character of many civil cases, or the lack of public interest for them, but also the style and manner of court procedure in civil cases. While the law proclaims that court hearings should be concentrated, and that civil proceedings in the first instance should ideally take place in only two hearings (one preparatory and one main hearing), most of civil trials still take place in multiple hearings which are weeks or months apart from each other. This style, which corresponds to the model of 'piecemeal trial,' ${ }^{33}$ is rather unsuitable for acquiring a public insight into the context and real meaning of the proceedings, as the public can only grasp discontinued fragments that hardly enable a meaningful scrutiny by the 'outsiders'.

In addition, despite the proclamation of the orality ideal, the written evidence is increasingly important, and the court and the parties at the court hearings often only refer to their written submissions and documentary evidence without orally summarizing their content. Thus, public participation at the hearing is often meaningless, an element of pure formality. Obviously, the publicity of civil 'trials' is not something that is counted on, as most of the civil hearings take place in small offices of individual judges which do not even have adequate facilities for participation of anyone outside of the inner circle of litigants.

On the other hand, to revive publicity as the tool to secure transparency, the right of public insight into the court files gains on importance. However, while the content of the court files is generally public, in practice there are multiple obstacles. While anyone can attend the hearings, for access to court files a permission is needed, and it is only given to those who show a 'legitimate interest. ${ }^{34}$ But when, in a lengthy process, the permission is eventually granted, only brief access to a particular file is allowed, with rather limited and costly possibility of copying and very limited options for thorough study of the file. Therefore, for the intere-

32 See Art. 307 CCP.

${ }^{33}$ For the notion of 'piecemeal trial' see Mirjan Damaška, Faces of Justice and the State Authority, Yale UP, Yale, 1986, 51-53, 57, 62.

34 On 'legitimate interest' (opravdani interes) and the differences between public access to court hearings and public access to court files see Siniša Triva, Mihajlo Dika, Građansko parnično procesno pravo, Narodne novine, Zagreb, 2004, $\$ \$ 25 / 5$ and 33. 
sted public (and even for the legal experts) it is rather difficult to put themselves in a position comparable to the position of the well-informed adjudicator.

Indeed, this also reduces the chance for meaningful public comment on the course of civil hearings. While in the cases of public interest the media can afford to wildly guess what is going on in concrete cases, most experts - if scrupulous give only general observations and refrain from concrete comments due to lack of relevant information. Therefore, the quality of public debate on ongoing cases is rather low.

The critical comments on the conduct of concrete cases are also not well received by the judiciary, even when the comments are accurate and well-balanced. The professional association of judges often protests public comments in ongoing matters. They raise the argument that all comments on pending judicial matters exert an undue pressure on courts and judges and prejudice the outcome of the pending cases. It was held that commenting pending cases amounted to criminal behavior and constituted a criminal offence of 'obstruction of justice.' For some time, criminal law indeed provided that public opinions which voiced how judges should decide in pending cases amounted to a criminal offence. As these arguments were used in practice to hush legitimate criticisms, and several people, including journalists, were prosecuted because they commented on pending cases, the criminal law was amended and this criminal offence was ultimately deleted. ${ }^{35}$ But, the reluctance of judiciary to receive public criticism remained until today.

In an attempt to improve the public picture of national judiciary and establish a dialogue with the public, the Law on Courts introduced in 2005 the office of 'court spokesperson. ${ }^{36}$ This spokesperson is a judge or other employee of the court designated to give information on the work of the court.

Gradually, the spokespersons have been established in most of larger Croatian courts. Yet, this measure has had an ambivalent effect. While it helped steer the public queries and media questions by addressing them to a specific office in the court, the court spokespersons often give only information of limited usefulness, such as references to general legislative provisions. Also, the existence of this

35 Former Art. 309/2 of the Criminal Code (Kazneni zakon, Official Gazette 110/97, 27/98, 50/00, 129/00, 84/05, 51/01, 111/03, 190/03, 105/04, 71/06, 110/07, 152/08, 57/11, 77/11, 125/11, 143/12), omitted in Criminal Code of 2011 (Off. Gaz. 125/11, 144/12, 56/15, 61/15, 101/17, 118/18, 126/19 - compare current Art. 312 CC).

36 See Art. 31 of the 2005 Law on Courts (Zakon o sudovima, Official Gazette 150/2005, $16 / 2007,113 / 2008,153 / 2009,34 / 2010,116 / 2010,27 / 2011,57 / 2011,130 / 2011,28 / 2013$ ), currently Art. 42 of the 2013 Law on Courts (Official Gazette 28/2013, 33/2015, 82/2015, 82/2016, 67/2018, $126 / 2019)$. 
office further reduced the willingness of any other judicial official to respond to questions by public media, thereby again contributing to the public picture of judiciary as a closed elite immune to criticisms and unwilling to engage in substantive discussions on relevant social matters.

\section{Judicial asset declarations as a device for prevention of corruption}

Another device for securing transparency of judicial office, but also for securing accountability of judges, is the obligation of judges to report on their assets. This obligation should show that judges live on their legitimate judicial income, and thereby prevent any illicit enrichment stemming from corruption or activities incompatible with the judicial functions.

The obligation for judges to submit regularly their asset declarations was introduced by the Law on State Judicial Council in 2010. ${ }^{37}$ This obligation is not specific for judges, as all other public officials also have obligation to regularly report on their assets. Still, there are differences between asset declarations for judges and for other public officials. The asset declarations for public officials are being kept under the Law on Prevention of the Conflicts of Interests by the Commission for the Decision on the Conflict of Interests, an independent state body. The asset declarations of judges are submitted to the State Judicial Council, which is also only competent for their keeping. The asset declarations for state officials were from the beginning a part of the public register which has been publicly accessible on the internet since 2013, while the information on asset declarations of individual judges were only given per request, when the State Judicial Council regarded that it was justified. The requests by the private parties to have an insight into the register were regularly rejected. Still, in order to make another step towards transparency and to equalize the position of judges and the state officials, since September 2018 it is provided that the asset declarations of judges will also be publicly accessible on internet pages of the State Judicial Council, in the form that excludes the data protected by the rules on protection of private data. ${ }^{38}$ However, the asset declaration were not available to public for over two years, which was justified by a number of technical and legal reasons (among others those related to protection of private data). Ultimately, the judicial asset declarations became finally available online in January $2021 .{ }^{39}$

37 See SJC, Arts. 87-88b.

38 See Art. 88.a SJC, as introduced by 2018 amendments (Official Gazette 67/18) and amended by 2019 amendments (Official Gazette 126/19).

39 See https://imovinske-kartice.pravosudje.hr/javno, last visited 29 April 2021. 
In the beginning, some judges were reluctant to submit their asset declarations. The obligation to submit asset declaration is relatively comprehensive and requires regular annual submission of information on real estate, movables, business shares, savings and other assets of higher value for judges, their spouses and minor children. Due to a silent boycott of a number of judges, the Law on State Judicial Council inserted a separate disciplinary offense of failure to submit the judicial asset declaration to the list of offenses, and about 20 judges were sanctioned by admonition due to this reason in 2015 and 2016. Since that event, all judges have regularly reported their assets. Still, it is early to give a full assessment whether and to which extent this obligation successfully contributes to the fight against corruption in the judiciary and to the accountability of the judicial power in general.

\section{Systematic publication of legal sources and judicial decisions}

As stated above, at present the publicity of court hearings does not have the same weight as originally envisaged. In order to secure accountability and transparency, ex post facto devices of control have more importance. Hereby, I refer to the ability to systematically analyze judicial decisions and assess all legal arguments raised in them.

The first and necessary precondition is that the legal sources are accessible and known to public. For Croatia, a country which adheres to tradition of written laws and statutes, it means that in the first place these acts need to be public and freely accessible.

In this respect, the situation is relatively good. Traditionally, all laws passed by the Croatian Parliament (Sabor) and most by-laws and regulations are published in the Official Gazette (Narodne novine). Starting from early 1990s, the Official Gazette is publicly accessible free of charge on the internet. ${ }^{40}$

Compared with the publication of general legal acts, the situation with the publication of court judgments and other judicial decisions is less satisfactory. Traditionally, only brief excerpts from judgments of the higher courts used to be published in a limited number of professional periodicals.

Yet, as a result of a PHARE 2006 project of international cooperation, a web portal of the Supreme Court is established with the aim to publish full text of all decisions of this court, as well as the most important decisions of the other courts. The result is that all judgments of the Supreme Court issued since 1990,

40 See https://narodne-novine.nn.hr/, last visited 29 April 2021. 
with only some exceptions (anonymization; formal decisions) as well as its general legal opinions are available online and free of charge. ${ }^{41}$

Still, the transparency in respect of publication of Supreme Court decisions is not without flaws. Due to the process of anonymization and other factors, the publication of the Supreme Court decisions, instead of being instantaneous in an online form, sometimes takes several months or even years. Also, the anonymization and the fact that Supreme Court judgments refer to publicly unavailable decisions of the lower courts regularly obscures the full social context of the cases decided by the SC. Further on, the search engine at the court's internet portal is incomplete and hardly functional, making it very hard to find specific information.

But, more importantly, only the decisions of the Supreme Court are at present available in full, unredacted form. The decisions of the appellate courts are published only as a brief and incidental selection of their jurisprudence, and the decisions of the first instance courts are generally not available online at all. All this shows that there is still a lot of space for improvement, and that the journey towards a truly transparent system in which all decisions, with rare exceptions, would be easily found and be fully accessible online is only starting. The 2019 reform of the second appeals (revizija) which introduced additional admissibility criterion that requires demonstrating divergent case-law at the level of appellate courts urges a quick and comprehensive action and expansion of case-law publication to all relevant decisions of the higher courts. ${ }^{42}$ Unfortunately, it seems that, at present, no significant steps are undertaken to match the new obligations of the parties and the new role of the Supreme Court with instruments that provide the indispensable transparency to the principal addressees of these legislative changes.

\section{Regular and detailed information on data relevant for quality and efficiency of the judicial system}

A truly transparent system of civil justice should also be able to demonstrate to the public that its overall functioning is appropriate. Relevant statistical information on the operation of the justice system, starting with the individu-

41 Compare https://sudskapraksa.csp.vsrh.hr/home, last visited 29 April 2021.

42 See Marko Bratković, Revizija po dopuštenju, diss., PF Zagreb, 2018; Marko Bratković, "Revizija po dopuštenju: izazovi i dvojbe”, Novine u parničnom procesnom pravu (ed. Jakša Barbić), HAZU, Zagreb, 2020, 179-209; Alan Uzelac, Marko Bratković, "Croatia: Supreme Court Between Individual Justice and System Management”, Supreme Courts Under Pressure. Controlling Caseload in the Administration of Civil Justice, (eds. Pablo Bravo-Hurtado, Cornelis Hendrik Van Rhee), Springer, Cham, 2021, 127-152. 
al courts and ending at the level of national judiciary, must be available, accurate, detailed and complete.

In Croatia, the volume of available data on the quality and efficiency of the judicial system has increased as the result of introduction of digital technology, but also as a result of the European accession process in which hard statistical facts were used as indicators relevant for the entry into the EU. Unfortunately, the sheer volume has not helped quality and consistency of the content, in particular due to the fact that judicial statistics were increasingly politically relevant. For this reason, some data seems to be missing in the present reports, while the other have been 'redefined'. This makes regular monitoring and comparisons of judicial statistics, in particular when taken over a longer period of time, difficult or impossible, and affects the reliability of the data and their usefulness for serious scientific analysis.

In the Socialist period, relatively detailed statistics on structural elements of the judicial system (courts, judges and pending cases) were reported in the annual surveys of the Ministry of Justice. ${ }^{43}$ They continued until present days, in parallel with several other sources, like the annual reports of the State Attorney Offi$\mathrm{ce}^{44}$ and, from 2010, the annual reports of the President of the Supreme Court on the state of the justice system ${ }^{45}$. At the same time, since the establishment of the European Commission for the Efficiency of Justice (CEPEJ), Croatia has been submitting its national reports for the unified schemes of monitoring the functioning of the national justice systems of the Council of Europe countries. ${ }^{46}$

The available statistical information is diverse, but far from perfect. Many of the available sources of information duplicate the same data, but omit data critical for the ultimate users of the justice system (e.g. detailed information on the duration of court proceedings). For the transparency of the functioning of the justice system it would have been much better to possess one central access to all information, and to hold a more intense dialogue with the representatives of the public and with the academic community. This could improve the quality of data, but also its relevance for the public, as at present a lot of information is relevant only for the insiders - lawyers, judges and administrative officials ${ }^{47}$ - while some

43 See https://mpu.gov.hr/print.aspx?id=6719\&url=print, last visited 29 April 2021.

44 http://www.dorh.hr/Default.aspx?sec=645 last visited 29 April 2021.

45 http://www.vsrh.hr/EasyWeb.asp?pcpid=1072, last visited 29 April 2021.

46 See http://www.coe.int/cepej, last visited 29 April 2021.

47 For more thoughts on the need of changing the perspective of approach to civil justice issues see Alan Uzelac, “Turning Civil Procedure Upside Down: From Judges' Law to Users' Law”, Tweehonderd jaar/Bicentenaire Code de Procédure civile, Kluwer, 2008, 297-309. 
essential data which would be valuable to inform the public and secure the public confidence in the judiciary, thereby contributing to its accountability and transparency, is not a part of any systematic monitoring.

\section{CONCLUSIONS}

Accountability and transparency of the judiciary are always important. But, they are even more important if the public is not satisfied with the quality and effectiveness of judicial services. If the users perceive judiciary as a problem, imminent reactions, comprehensive debates and urgent measures are needed. Civil justice is the ultimate method of enforcement of rights of citizens and companies, and the society has legitimate expectations that it delivers what is expected. This is only possible when judiciary is accountable. The notion of accountability relates in particular to judges as those directly in charge of individual civil proceedings but needs to be taken much broader. Individual proceedings need adequate technical and human environment, good administration of courts and judicial system, and cooperation of all bodies involved in the shaping and operation of civil justice.

In order to secure accountability, the system needs to be transparent. The value of transparency is not only in formal publicity of the court proceedings, or in technical availability of court judgments. Transparency means that tasks and responsibilities in the civil justice system are clearly and logically distributed; that court decisions are consistent and understandable; that everyone can swiftly and inexpensively find relevant information on pending cases; that the outcomes and the length of judicial proceedings are foreseeable, both generally and in concrete cases; that judiciary is as a whole competent and effective, open to the needs of society, receptive of criticisms and free from bias and undue influence. All of that needs to be seen and felt by the public, and only under such preconditions will the public have trust in the judicial system.

In contemporary states, the public has right to expect higher standards of transparency and accountability than in the past. New technologies and digital processing of data have capacity to significantly raise the bar in respect of transparency. Unlike before, there is no good reason why all judicial decisions at all levels would not be publicly and freely available online. They should be available within minutes after they were made, with very few exceptions. There is no good reason why up-to-date information on the operation of the judicial system would not be automatically available as a byproduct of integral case management systems; and why every interested citizen would not be able to ask a logical que- 
stion on the functioning of courts and civil proceedings, receiving a complete and understandable answer within several minutes or hours. Finally, as judicial function is an important and generally well-paid office, the public has the right to be served by judges who are broadly educated, well-trained, effective, just, ethically impeccable and highly motivated to discharge their functions. If this is not the case, they should be held accountable.

The Croatian experience with accountability and transparency shows that customary approach needs to be redefined, in particular when establishing the fragile balance of independence and accountability. After 1990s, Croatia - same as many other Central and Eastern European countries - nominally embraced the doctrine of separation of powers. A particular element of this doctrine on which reforms were focused was the independence of judiciary. But in practice this independence was first disregarded, and later overemphasized, which in the end led to the situation in which judiciary is in the general public perceived as both unaccountable and dependent. A fresh start is needed - but this is at present virtually impossible, as the judiciary has developed into a closed, self-sufficient system (over) protected by a number of constitutional guarantees which would have been appropriate for a stable system in which judiciary is both competent, and highly respected and trusted. As this is not the case, a lot of these guarantees now seem to be outdated and counterproductive.

Prof. dr. sc. Alan Uzelac

Redoviti profesor u trajnom zvanju i

predstojnik Katedre za građansko procesno pravo

Pravni fakultet Sveučilišta u Zagrebu

\section{ODGOVORNOST I TRANSPARENTNOST U GRAĐANSKOM PRAVOSUĐU OPĆE ODREDNICE I POGLED IZ HRVATSKE PERSPEKTIVE}

Rezime

Rad iz hrvatske perspektive analizira pojmove odgovornosti i transparentnosti u nacionalnim pravosudnim sustavima. Produženo razdoblje tranzicije i dugotrajan proces pristupanja Europskoj uniji ukazali su na osobit položaj i važnost uspostavljanja neovisnog, ali i djelotvornog pravosudnog sustava. Potreba za osiguranjem mehanizama koji jačaju društvenu i pravnu odgovornost sudaca i drugih pravosudnih dužnosnika javila se posebno u kontekstu razvoja u devedesetim i prvim godinama ovoga stoljeća kada su, na krilima starih praksi, ali pod zaštitom preuveličanog i neprikladnog poimanja nezavisnosti pravosuđa, stvorene zatvorene pravosudne elite koje su postale 'država u državi'. Kronična neefikasnost i slabi sustavi odgovornosti traže novi pristup. U ovom 
radu se analizira osam sredstava i metoda za osiguranje odgovornosti i transparentnosti: disciplinske sankcije za nositelje sudačke dužnosti; pravila pravosudne uprave o upravljanju predmetima; kvantitativni kriteriji za evaluaciju obnašanja sudačke funkcije; mjere za osiguranje kontrole kvalitete sudskih odluka i jedinstvenu primjenu prava; mjere za osiguranje javnosti sudskih postupaka i javnog pristupa sudskim spisima; obveza prezentacije podataka o imovini pravosudnih dužnosnika (imovinske kartice sudaca i sl.); mjere za osiguranje javnosti sadržaja propisa i sudskih odluka; te mjere za osiguranje punog i sustavnog uvida u sve relevantne podatke o radu pravosudnog sustava. Opisujući tipične probleme u primjeni ovih sredstava i metoda u Republici Hrvatskoj, nastoji se ocrtati teme koje će općenito omogućiti novo promišljanje pristupu odgovornosti i transparentnosti u građanskim pravosuđima središnje i jugoistočne Europe.

Ključne riječi: građansko pravosuđe, odgovornost i transparentnost pravosuđa, Hrvatska, nezavisnost pravosuđa

\section{Bibliography}

Bell J., Judiciaries within Europe: a comparative review, Cambridge University Press, Cambridge, 2010.

Bratković M., Revizija po dopuštenju, diss., PF Zagreb, 2018.

Bratković M., "Revizija po dopuštenju: izazovi i dvojbe”, Novine u parničnom procesnom pravu (ed. Barbić J.), HAZU, Zagreb, 2020.

Damaška M., Faces of Justice and the State Authority, Yale UP, Yale, 1986.

Democratization and the judiciary: the accountability function of courts in new democracies (eds. Gloppen S., Gargarella R., Skaar E.), Cass, London, 2004.

Grgić A., "The length of civil proceedings in Croatia - Main causes of delay", Public and Private Justice. Dispute Resolution in Modern Societies (eds. Uzelac A., Van Rhee C. H.), Intersentia, Antwerpen-Oxford, 2007.

Hess B., Koprivica Harvey A., (eds.), Open justice : the role of courts in a democratic society, Nomos, Baden-Baden, 2019.

Independence, accountability, and the judiciary (eds. Canivet G., Andenas M., Fairgrieve D.), British Institute of International and Comparative Law, London, 2006.

Piana D., Judicial accountabilities in new Europe: from rule of law to quality of justice, Ashgate, Farnham, 2010.

Triva S., Dika M., Građansko parnično procesno pravo, Narodne novine, Zagreb, 2004

Uzelac A., "Role and Status of Judges in Croatia", Richterbild und Rechtsreform in Mitteleuropa (ed. Oberhammer P.), Wien, 2000.

Uzelac A., "The Rule of Law and the Judicial System: Court delays as a barrier to accession", Croatian Accession to the European Union (ed. Ott K.), IJF, Zagreb, 2004.

Uzelac A., “Turning Civil Procedure Upside Down: From Judges' Law to Users' Law”, Tweehonderd jaar/Bicentenaire Code de Procédure civile, Kluwer, 2008. 
Uzelac A., "Survival of the Third Legal Tradition?", Common Law, Civil Law and the Future of Categories (eds. Walker J., Chase O. G.), Lexis Nexis, Markham, 2010.

Uzelac A., "Ustavno pravo na žalbu u građanskim stvarima: jamstvo ispravnog pravosuđenja ili relikt prošlosti?”, Djelotvorna pravna zaštita u pravičnom postupku. Izazovi pravosudnih transformacija na jugu Europe. Liber amicorum Mihajlo Dika (eds. Uzelac A., Garašić J., Maganić A.), Pravni fakultet Sveučilišta u Zagrebu, Zagreb, 2013.

Uzelac A., "Delays and Backlogs in Civil Procedure. A (South) East European Perspective”, Revista de Processo, Vol. 39, 2014.

Uzelac A., Bratković M., “Croatia: Supreme Court Between Individual Justice and System Management", Supreme Courts Under Pressure. Controlling Caseload in the Administration of Civil Justice, (eds. Bravo-Hurtado P., Van Rhee C. H.), Springer, Cham, 2021.

Voermans W., "Judicial transparency furthering public accountability for new judiciaries", Utrecht Law Review, No. 1, Vol. 3, 2007.

Article history

Received: 03.05.2021.

Accepted: 22.05.2021.

ORIGINAL SCIENTIFIC PAPER 